\title{
COMPREHENDING CLASSROOM INTERACTION DEPICTED IN EDUCATIONAL VIDEO BY APPLYING TOP-DOWN AND BOTTOM-UP TECHNIQUE THROUGH LSLC BASED LEARNING
}

\author{
Rini Susilowati *)
}

\begin{abstract}
Abstrak
Artikel ini menganalisis tentang bagaimana Lesson Study for Learning Community (LSLC) berkontribusi pada hasil belajar siswa. Suatu pembelajaran berbasis LSLC di kelas menyimak telah diadakan oleh penulis untuk mengetahui lebih jauh lagi bagaimana suatu pembelajaran kolaboratif mempengaruhi kemajuan siswa. Tujuan artikel ini adalah memberi gambaran bagaimana siswa memahami interaksi kelas yang digambarkan dalam video pembelajaran dengan pengaplikasian tekhnik top-down dan bottom-up melalui pembelajaran berbasis LSLC. Hasil pembelajaran di kelas menunjukkan bahwa dengan mengelompokkan siswa ke dalam distribusi kelompok yang setara dapat menarik siswa untuk mempunyai keberanian yang lebih besar dalam mengekspresikan pendapat, menunjukkan empati bagi setiap anggota kelompok dalam memahami materi, dan memiliki tujuan akhir bahwa setiap anggota kelompok harus mendapatkan pengetahuan yang sama. Di luar perbedaan tingkat pemahaman yang disebabkan oleh kemampuan siswa, pembelajaran berbasis LSLC berhasil membuat siswa memiliki usaha yang lebih untuk meningkatkan potensi diri mereka.
\end{abstract}

\section{Kata kunci: Interaksi kelas, tekhnik top-down, tekhnik bottom-up, pembelajaran} berbasis LSLC.

\section{Introduction}

Listening is the process to obtain certain message from any kind of spoken material. Listening in English is the process obtaining messages from some kinds of spoken English discourse through hearing system. Brown (2007:301) state that listening is the process of getting the message of others say through auditory channel. Listening involves someone's critical thinking as well as the hearing system used to grab the message delivered from the spoken things. Listening critically requires someone not only listen and obtain the message but also identify kind of discourse and its purpose of why it is produced. Brown (2007:301) explain that somoene whom listened to someone's talk should distinguish kinds of speech delivered and catch the message of it. Moreover, listening critically also requires someone to react and respond appropriately depend on the discourse delivered. Conversation requires someone to respond by giving certain comments, expressions, statements or sometimes questions. Information need to be analyzed in order to get the gist of the significant value from it. Request and offers demand people to do something depend what needed and also make give something or help to someone else. Meanwhile, as the listeners, the students should be able to think critically the way the speakers on the spoken material 
talk to each other and how they react and respond to the people whom they talk to. For example, when the students listen to a short conversation related to health between two persons they should recognize the topic of their talk and some details such as; where do they talk, why are they in a hospital, what health problems suffered by one of the speakers and the other things. comprehending short conversations related to daily activity topic considered as not really a difficult matter for the students but the the longer spoken material can be such an obstacle for them to be comprehended. Longer spoken material can be narrative, speech, lecture, and classroom interaction. One of the spoken material that discussed further in this article related to material learnt by the students in the class is classroom interaction.

Classroom interaction involving teacher as the source of knowledge and information from many disciplines and students as the learners who quest for the new things in their life to make their lives better. Classroom is the formal place where most of learning activities occured and interaction is the main activity between teacher and students in the classroom. According to Ojedekon \& Okewole (2011) in Bawa, Nura, and Zubairu (2015:72), classroom interaction involves reciprocal actions that take place in a room, in a school, between the teacher and the students. This implies that the teacher formally instructs the students. Classroom interaction demands the teacher to communicate their thoughts, knowledge, ideas, and other things related to educational purpose. Meanwhile, the students should be aware of what teacher delivered by thinking, understanding, and analyzing critically in order they gain new knowledge which support the development of their potential during their learning time. Classroom interaction discussed in this article is related to the real situation of the class or it called as authentic material played in the video. The writer used audio visual media in her teaching to give the real depiction of how teacher and students interact in the class. Learning in listening class through hearing and seeing will be more helpful for the beginners since the learners in the writer's class are the first semester students of English Education Study Programme. They still in the process of enriching their vocabulary and knowledge so that the use of educational video aimed to diminish their problem in understanding the content of spoken material they hear. According to Greenberg and Zanetis (2012:4), Video appears poised to be a major contributor to the shift in the educational landscape, acting as a powerful agent that adds value and enhances the quality of the learning experience. Relating the content of the conversation to the general topic being spoken as well as to the context of the visual things they watch will overcome students' problem in comprehending the learning 
material. Greenberg and Zanetis (2012:5) state "pedagogical impact of video can be summarized by three key concepts: Interactivity with content, engangement, knowledge transfer and memory". Interactivity with content helps the students to relate the content of the spoken material to visual content by connecting some verbal things in the video to its visual and get general understanding. Engangement demands the learners to connect the visual content to the spoken material and draw the conclusion about what they hear and see. Knowledge transfer and memory relate to students' capability to remember things they hear and see and to keep certain concept on their mind. Furthermore, educational video can engange students' interest to focus and to enjoy on things they hear because the visual depiction can excite them. The visual effects resulted from the video can increase students' enjoyment in learning since they are easily get bored to nonvisual spoken material which difficult to be understood because they do not understand some difficult words or terms used. According to Greenberg and Zanetis (2012:5), Because video combines many kinds of data (images, motion, sounds, text) in a complementary fashion, learning can be adjusted more easily than with other tools to the diverse learning styles and individual learning pace of students. With video, the learner has more control over the information he receives and an additional opportunity for deeper learning.

Because the course taken by the students related to listening for educational so the material in the video cover all things related to classroom interaction from different level classes, different material and different teching method. The activity mostly done by the students are analyzing the teaching method used by the teacher in the video played, understanding material delivered by the teacher, recognizing the media used by the teacher or the other tools and equipments involve in the learning, and how the students in the video learn and understand the material. Using educational video in listening class help the learners to diminish learning obstacles often suffered when they are in the beginning of the course learning where they still develop their initial potential to master their skill in listening. Some common obstacles often experienced by the learners in the beginning level when they are in listening class are following the rushing spoken material they hear, understanding the meaning of difficult words, accents and rate of delivery of the native speaker, forms of reduced clause often used by native speakers, idoms used by the speaker. First, following the rushing material they hear. Listening is a process involving not only hearing system but also our mind, concentration, and the practical use of our hand to put all important things in such kind of note. Listening requires students 
to catch up spoken things fast as well as to understand the message behind it. There are no pauses among some parts of the spoken things where the students should not miss anything. If some parts are missed in their hearing probably it will result in confusion unless they ask for repetition. In some cases, repetition does not work much if students have lost their concentration because of confusion in the previous part. Brown (2006:3) states "The language comes rushing in at them. Listening must be done in real time; there is no second chance, unless, of course, the listener specifically asks for repetition". Second, understanding the meaning of difficult words. Since the spoken things produced by native speakers, the students often find some difficult words just because of native speakers' fluent pronunciation, accent and speed of speaking. Fluent pronunciation makes some familiar words seem to be the new words for the students. Meanwhile, the students also often find the unfamiliar words if the topic is out of their prior knowledge. Third, accent and rate of delivery of the speakers. Different native speakers share different accents which influence to the way they pronounce words. British English accent is more difficult to be understood because of its fluent pronunciation and certain rule of sounding some phonemes. Fourth, forms of reduced clause often used by native speakers. Native speakers tend to use more casual and effective language especially those who use American English accent. They like to ommit certain parts of the clauses, such as they reduce " $\mathrm{i}$ have arrived in the airport at ten a.m." to be "i've arrived at ten a.m." and "she will get her salary this week" to be "she'll get her salary this week". It results to students' confusion because they are not aware of some kinds of reduced clause. Anytime they find unidentified reduced clause they think that it is difficult term for them. Those obstacles such barrier for the students and it often distracts the process of obtaining the gist of spoken material. Considering the neeed of the students to have more conducive learning the writer made such decision to apply two techniques in her teaching which are top-down and bottom-up technique.

Technique used in the instruction takes significant role to help the students to have more fruitful learning. The technique applied should match to the need and condition of the learners in order the learning process will not be such burden for them but it becomes something which educates and excites them. Top-down technique leads the students to have connection between the content of spoken material to their prior knowledge. They generalize the content of things they listen through what they understand of the topic. They relate it to their knowledge they get by reading, writing, speaking or even when they watch television. Personal experience can also be one source to support 
them to comprehend the spoken material. This technique seems more practical but it often makes the students having obstacles to find some details of information. Top-down means using our prior knowledge and experiences; we know certain things about certain topics and situations and use that information to understand (Brown, 2006:2). Meanwhile, bottom-up technique help the students to gain the meaning of the target language by connecting words, clauses, or phrases. Finding some important key words and having its meaning by translating, looking to dictionary and whole class discussion are the activities in bottom-up technique to obtain the idea of what they listen. Brown (2006:2) states "Bottom-up processing means using the information we have about sounds, word meanings, and discourse markers like first, then and after that to assemble our understanding of what we read or hear one step at a time". The combination of two techniques is more effctive to overcome students' problem in comprehending the spoken material they hear. Anytime the students having minimum prior knowledge toward the topic exposed in the spoken material, bottom-up technique gives contribution by leading the students to comprehend it by getting and understanding some difficult words, phrases, and clauses. Meanwhile, the techniques used should be supported by the effective learning and method which can engange the students to have more motivation to defeat learning obstacles they face. The writer applied Lesson Study for Learning Community (LSLC) as a collaborative process as well as collaborative learning in the attempt to make learning to be more fruitful and effective.

\section{LSLC; its definition, advantages and general stages}

LSLC is a collaborative process or collaborative learning in which the students are divided into some groups and they support one another to make progress for each of individual specifically and the whole group's achievement in general. LSLC is a kind of learning in which a group of teacher or lecturer having cooperation and collaboration to have certain teaching plan by following some steps which are organizing learning design, planning, observing and analyzing, reflecting and revising the learning design. According to Dudley (2012:2), Lesson Study ( LS ) involves groups of teachers collaboratively planning, teaching, observing and analysing learning and teaching in 'research lessons'. They record their findings. An LSLC based learning should be aimed to overcome some learning problems and obstacles often faced by the teachers and the students specifically. Teachers should be aware of their own way of teaching whether it has fulfilled the target. Delivering material is not necessarily important unless the students having high interest and motivation to learn, 
being enganged to be active in the class by elaborating their critical thinking in order to keep every concepts they learnt in the long memory. Some beneficial advantages can be obtained by teachers as well as the students from LSLC. LSLC can be such reflection for the teachers of how they teach, whether the learning outcome has reached the target or not. If it has not reached yet, teachers should change their teaching method. LSLC can be such a strategy to solve the problem by conducting a collaborative learning involving groups of teachers or lecturers. Meanwhile, for the students LSLC can engange their critical thinking, cooperation, empathy as well as self awareness toward someone else's learning problems. In this kind of learning students are hoped can support one another by sharing their knowledge and understanding of the material learnt so that each of group member can obtain more or less the same learning outcome. Furthermore, teachers or lecturers can obtain a lot of input from the other teachers or lecturers as their acquintances through their observation in the class. The result of the observation can really help model teacher or model lecturer to know further about how each student learn in the class, the way they concern to the material, their understanding of the material, the way they interact with every members in their groups, and how they share each other in learning. Rusman (2010:394) in Anggara and
Chotimah (2012:190) state that there some advantages of LSLC which are;

Improving teachers' knowledge of the material and its learning process, improving teachers' knowledge of how to observe students' activity, mantaining the partnership among teachers or among the other observers who not having proffession as teacher, connecting each learning to have a final goal which result maximum learning outcome in the future, increasing teachers' motivation to develop their own knowledge and skill to have better teaching, improving teaching plan with its components including teaching material and learning strategy.

Many problems appear in learning such as the use of method, strategy, learning media, learning instruction as well as the atmosphere in the class. Considering those problem, in LSLC based learning a teacher or lecturer should think of what needed in the class related to some components stated previously. Firstly, a teacher or lecturer should focus on certain course they want to teach in the class. Before conducting a collaborative learning based on LSLC, a teacher or lecturer arrange learning plan called lesson design. The teacher or lecturer who conduct this kind of learning called model teacher or model lecturer. She or he should prepare such lesson design in which there are some time allocations for some activities such as preactivity, while activity, and closing. In preactivity teacher or lecturer provide brief 
explanation of material taught to brainstorm the students' mind. Meanwhile, in while activity the teacher or lecturer should prepare some tasks for the students and the tasks should be divided into some jumping tasks. Jumping tasks means the challenges given to the students to be accomplished with their groups. The jumping tasks should be related to the material discussed in the class and teacher or lecturer should direct clearly how the students work on that jumping tasks. After lesson design has been arranged completely, a collaborative learning based on LSLC can be conducted. It is determined as collaborative learning because model teacher or model lecturer should apply one kind of learning model of collaborative learning method to be applied in the class. After that certain material, strategy or technique, method of collaborative learning and media should be prepared. The next step is conducting LSLC based learning in the class called open lesson. There are some stages that should be passed in LSLC based learning.

\section{Some Stages in Applying LSLC based Learning}

Some stages should be passed in LSLC based learning which are plan, do, and see. Dudley (2011:6) states “A Lesson Study consists of a cycle of at least three 'research lessons' that are jointly planned, taught/observed and analysed by a Lesson Study group". When conducting an LSLC based learning the teachers should have at least three cycles in order to get obvious learning activity with its learning outcome. Every one meeting in the class considered as one cycle. One cycle consists of three stages which are plan, do and see.

\section{Plan}

In this stage model teacher or model lecturer should prepare some components of teaching such as lesson plan, teaching media, teaching method (in this case teacher should apply one model or strategy of cooperative learning or approach) because LSLC based learning is kind of cooperative process of learning. Furthermore, the teacher should also prepare learning material, lesson lesson, and worksheet for the students. The preparation of those components should be based on some considerations which are; students' need related to material they should understand and master, students' problem which should be overcomed, effective teaching method and media that can engange students to have better learning outcome, and one model of cooperative approach which can stimulate the students to be more critical, active, and having more fruitful understanding about the material. After each teaching components have been well prepared, the next stage which is $d o$ is ready to be conducted. The activity of teaching in the classroom called as open lesson. Before open lesson begins model teacher and some observers gather in a room 
to discuss about teaching plan designed by model teacher. In this occasion model teacher explain brieftly about lesson design she or he has prepared and the observers give their response and comment.

\section{Do}

There are two activities in $d o$ stage which are teaching done by model teacher and observation done by the other teachers. Model teacher teach based the lesson plan prepared. At the beginning of teaching model teacher gives introductory explanation related to material. The explanation should be clear, understandable, and supported by examples and theories. After the teacher deliver the material, the teacher ask the students to do some tasks through discussion. Teacher should guide the discussion so that it run as what has been expected. Meanwhile, the observers notice to how the students learn and discuss their tasks. The observation should describe clearly about students' manner in learning, the way they discuss and share to each other, and the way they complete the tasks. Furthermore, the result of the observation will help model teacher to reflect whether the learning process has run as what expected or not. If there are still some problems suffered by the students, model teacher should rearrange her or his lesson design for the next cycle in order to have better learning outcome.

\section{See (reflection)}

In the last stage of the cycle model teacher and the observers gather and discuss the result of learning process. Model teacher comment on learning process objectively whether it has fulfilled some targets or not. Meanwhile, the observers report the result of their observation by describing clearly and obejectively how the students learn in the class. For example; whether the students really comprehend the material thoroughly, do they really participate actively in the class ( all of the students, half of the students or even only some of the students), do they learn and discuss the material seriously or they just copy their friends' answer on the worksheet without effort to do it through analyzing and discussing with the group. In a short, see stage can be such a beneficial input for model teacher to improve learning process to be better especially for students' progress.

\section{Applying LSLC Based Learning in Listening Class}

The writer of this article has conducted LSLC based learning in listening class for three cycles by considering that the students are the first semester students who still develop their listening skill and they are assumed to have some learning obstacles in understanding spoken English material. Besides, the open lesson which conducted is expected can inspire the students to have awareness of the advantages of learning 
through a cooperative process. They are hoped to have such a view that learning together with cooperation principle and strong commitment will result in a good learning outcome. The open lesson was conducted in listening class of the first semester students. The course is listening for educational purpose. Based on academic guidance book the material of this course cover some classroom interactions in various setting. The material specifically focus on the method used by the teacher to teach, learning strategy applied, learning media and how the teacher and students interact to each other. Because the three cycles done in the first three meetings of the semester, the material cover form of classroom interactions in elementary school. The writer used audio visual media which is learning video which depict classroom interaction of elementary school in India. Meanwhile, the learning model of cooperative approcah applied by the writer was student team achievement division (STAD). In STAD the students were divided into small groups consist of five to six members. The basic principle in STAD is individuals' achievement depends on how every group member supporting each other. There were four groups consist of five members and two groups consist of six members. The members chosen based on different gender, race and capability. Since the three cycles conducted in the first meeting of the semester and the writer has not known yet each individual's capability, the writer chose them randomly by avoiding to take students who often sit together side by side. This strategy took by considering that every group had equal group distribution. The next part of this article will discuss further of how the process of open lesson conducted.

\section{First cycle}

Before the writer taught in the first cycle, she explained her lesson design to the observers. She explained her teaching plan related to the course, the class and semester in which she taught, the material, teaching media and the method used. The observers gave their comments on it. In the first cycle the writer gave material about classroom interaction of elementary school in India. The material taught by the teacher in the video was prepositions. The teacher used some puppets to tell a story about jalu, a puppet which its ear is missing. Some prepositions are integrated in the story through the characters' utterances. The teacher in the video also used demonstration by using gestures to show some positions of objects when it put on the other object, such as on the table and under the table. Other than using puppets, the teacher put a poem in students' task in which in the poem the students could find some examples of preposition. Before the writer played the video, she explained briefly about classroom interaction and asked some questions to engange the students to have a vivid description of classroom interaction in 
their mind. After that she asked the students to give some examples of classroom interaction. The writer used top-down technique and asked the students to use their prior knowledge about classroom interaction. Generally the students had a clear concept of classroom interaction and they could give example of classroom interaction. This activity done in opening activity. Furthermore, the writer played the opening activity in the video and asked the questions. In this part many students still looked confused because of some difficult words that they do not understand. The writer asked the students to understand the general content of opening activity and guided them to answer some questions by giving some explanation of difficult words. Although there were still few students who gave response toward the writer's questions, generally the whole class understand about the concept of classroom interaction.

The next activity was while activity. The writer played the main part of the video and asked the students to discuss the teaching method and media used by the teacher. At the beginning the students were still confused and to anticipate it the writer gave brief explanation about what is teaching method and teaching media with its examples. In this case, the writer used top-down technique and asked the students trying to understand globally about the way the teacher teach using their prior knowledge. For example, the writer asked the students to relate their experience when they learn in the past of how their teachers taught them. Besides, relating the visual context helped them to recognize the teaching method and media used since they could see clearly how the teacher taught in the video. Only few students responded to this activity.

The next activity in while activity was watched the next part of the video. The writer asked the students to focus on some details of the material taught and analyze how the students in the video do their tasks with their group. Globally the students were aware that the material was about prepositions and they could recognize some examples of prepositions mentioned by the teacher in the video. Some students from certain group could give the example of preposition in the video. The difficult thing was following the poem. The teacher in the video prepared one poem and in each line of the poem there were prepositions found. The writer asked the students to understand the meaning of each line. Some groups were still confused and the writer gave the translation of some difficult words by giving definition and example. In this occasion the writer used bottom-up technique. Finally, they got more understanding and could finish the task with the groups. Nevertheless, not all groups gave their contribution in sharing session. Some members in one group looked very active and many members in other groups looked 
passive. It seemed there were still many students who did not courage to speak their mind. Finally, the writer closed the first cycle by giving some conclusions.

Some observers joined the class to observe and noted some important findings during the first cycle. There were three observers in the class. Based on the notes explained by the observers during see (reflection) stage the composition of group was not equal. Some active students were in the same group while there were still many passive students in the other groups. The were only some groups which contributed to sharing session. Considering some important notes from the observers the writer planned to change the composition of the group to be more equal since the writer herself has not known yet exactly the students' capability.

\section{The second cycle}

Plan stage was done before the second cycle conducted. Some plans related to teaching plan explained to the observers. Based on the suggestion from the observers in cycle 1, the writer has changed the composition of the group to have more equal group distribution. Some active students should be put equally in every group with a hope they can stimulate their friends to be involved actively in group discussion. In the second cycle the writer taught classroom interaction of elementary school with material about idiom. Learning video still used to give clear description of class situation and learning model used was STAD. In opening activity the writer played the first part of the video and asked the students to identify whether teacher used ice breaking to open the class. Before the students having discussion, the writer explained brieftly about ice breaking. After having discussion some groups gave their response about ice breaking made by the teacher in the video and its purpose.

In while activity the writer played the main part of the video in which the teacher taught about idiom. Then by using top-down technique the writer guided the students to recognize and to analyze the teaching method used by the teacher in the video using their general understanding and prior knowledge. The students discussed it with their groups. The result showed that generally all groups known that the teacher in the video used verbal explanation combined with the use of paper on the board to show some paragraphs in which there are some idioms in it. Some groups shared their opinion with their representative. Some group members who have not ever talked before seemed to talk in this cycle. Meanwhile, to understand the material taught by the teacher in the video the writer used bottom-up technique. The writer asked the students randomly to read four paragraphs in the video. Many students from different groups seemed to be motivated to be volunteer. Each time they finished to read the 
writer asked some questions to understand the story behind the paragraph. Many students seemed interested to give their opinion. Some difficult words are explained by the writer using explanation, example and definition was the last choice. The writer asked the students to focus to each sentence and its meaning. Whether the meaning produced from each sentence is literal meaning or the other meaning behind the real meaning. The students discussed it with the groups and every groups seemed to understand that the material was about some utterances related to special meaning or the other meaning beyond the words. The problem was they did not understand the English term of it. The writer informed them that English term was idiom. The last activity in while activity was identifying idioms found in the paragraphs and its meaning. Many students from different groups were interested to give their answer. The number of students who involved in sharing session was increased than in the first cycle.

The last stage of this cycle was see (reflection). During the sharing session the observers reported that many students from different groups were active in group discussion and sharing session with the class. The writer concluded that the result of learning in second cycle was better than the first cycle. The changing of group composition worked well.

\section{The third cycle}

The third cycle begun with plan stage as usual. The writer explained that the material still about classroom interaction in elementary school. The material taught in the video was about describing objects and it was in the conversation class. Learning video was still used and learning model of cooperative approach was still STAD. Some jumping tasks (the challenging tasks for the students) have been prepared.

In $d o$ stage the writer played the opening part of the video and asked the students to discuss with the groups why the teacher in the video showed handphone to the students. In this case the writer used top-down technique by asking the students to have their global understanding in comprehending the opening part of the video. The students seemed did not find difficulty to understand some utterrances used by the teacher and students in the video. They could relate to the visual context and concluded that the teacher in the video showed handphone to attract the students to speak and to describe some objetcs. Many groups shared their answer.

In while activity the writer asked the students to focus on the teaching method and material taught by teacher in the video. In this case the writer used top-down technique since the students were only asked to identify the teaching method and material. They could identify the teaching method by relating to visual context described in the video. All 
groups agreed that the teacher in the video using some objects to teach. Meanwhile, the material was about describing objects. In the next activity, the writer asked all groups to identify all objects described by the students with its description. The result showed all groups invite their representatives to share their answer. Many students who never talked before in sharing session showed their effort to express their opinion. It seemed that the cooperation among group members has run well. Each group member supported each other to understand the material. The tasks can be finished completely.

The last stage in this cycle was see (reflection). Based on some observers' comment the cooperation in all group run well. The method and material as well as the video can engange the students to understand the material. Everyone in all groups tried to be involved actively in the class.

\section{Conclusion}

Managing the class is not easy unless we are the people who involve in it who should try to make class situation into fun, interesting and enjoyable. Students have different characters and they also bring different manner in the class. Teaching clever, extrovert, and critical students does not really spend our effort since they are tend to have self-regulated. Reading books, focusing on explanation in the class and being active in class discussion such ways for them to increase their potential. Meanwhile, managing students who have low effort, motivation, interest and capability is more difficult. LSLC based learning remind us that learning is not only a matter of delivering material completely, but it is a process of developing every students' potential in the class. Our students really count on our effort and strategy in reaching their learning goal. LSLC based learning has given message to us that a hard task will be easier to be accomplished if we work together. Learning cooperatively can teach the students about empathy, understanding each other, sharing and making achievement together.

\section{Reference}

Bawa, Nura, \& Zubairu, S. (2015). Constructivism and classroom interaction. The International Journal of Modern Social Sciences, 4(2): 7181 .

Brown, D. H. (2007). Teaching by principles an interactive approach to language pedagogy. White Plains, NY: Pearson Longman.

Brown, S. (2006). Teaching listening. New York, NY: Cambridge University Press.

Dudley, P. (2011). Lesson study UK. (A Handbook).

Greenberg, A. D. \& Zanetis, J. (2012). The impact of broadcast and streaming video in education. (A Report). Wainhouse Research. 
Anggara, R. \& Chotimah, U. (2012). Penerapan lesson study berbasis musyawarah guru mata pelajaran (MGMP) terhadap peningkatan kompetensi profesional guru Pkn SMP se-kabupaten Ogan Ilir. Jurnal Forum Sosial, V( 02), 188-197. 